\title{
Geological photogrammetry using oblique aerial photographs
}

\author{
Keld S. Dueholm and Asger Ken Pedersen
}

Large areas in Greenland are covered by oblique aerial photographs, taken with $23 \times 23 \mathrm{~cm}^{2}$ photogrammetric cameras of the type 'Eagle' between 1948 and 1953. Though almost all of Greenland is now covered by modern vertical photographs, the oblique photographs still represent a valuable alternative source of geological information because of the perspective at right angles to the mountain side. So far, geologists have only been able to use the oblique photographs for visual interpretation.

New photogrammetric instruments like the Kern DSR 11/GP1 Analytical Plotter at the Institute of Surveying and Photogrammetry, the Technical University of Denmark, make it possible for geologists to map precisely from oblique photographs. This report describes an experiment where such photographs have been used for mapping of steep mountain sides for the production of geological maps, cross-sections and perspective views. Earlier results are reported by Dueholm \& Garde (1986) and Heinesen (1987).

\section{Experimental area}

Current geological investigations along the south coast of Nûgssuaq and in northern and eastern Disko (Pedersen, 1985; Pedersen \& Larsen, 1987; Larsen \& Pedersen, 1988) concern Tertiary lavas and hyaloclastites, and their interaction with clastic sediments of nonvolcanic origin. Volcanic units are traced from close to their eruption sites, where they originate as subaerial lava flows, to where they enter water-filled basins and develop into subaqueous lava flows and hyaloclastites which may show impressive foreset bedding. The volcanic units often encounter and interact with sandstones and mudstones from the Upper Atanikerdluk Formation (Koch, 1959). Accurate mapping of chronostratigraphic volcanic horizons from subaerial to subaqueous facies is important for integrated basin analysis.

The lithological units mapped are lava flows or sequences of lava flows, or hyaloclastite beds, which may be distinctive through variation in thickness, morphology or colour.

\section{Photogrammetric orientation}

Altogether four pairs of oblique photographs were analysed; the results from one stereo pair 514G1-N $\varnothing$ nos 8840 and 8841 from 1949 taken with an Eagle camera no. 15 is used as an example (fig. 1). The Eagle cameras used in the 1940 s and 1950 s for oblique photographs are not of the same quality as modern photogrammetric cameras. To increase precision it is therefore important not only to know the calibrated focal length of the camera, but also to obtain the calibration reports of the camera at the time of operation. Fortunately, the Geodetic Institute, Denmark, who took the photographs in 1949, can provide such reports for both cameras used in the experiment.

The Eagle camera has eight fiducial marks (réseau marks). Average residuals for an affine transformation of the measurements to the calibrated coordinates are about 25 microns. This is a relatively high value compared to the results obtained with modern cameras and film types, but it is not of great significance in the present experiment, and we were able to orientate three of four stereomodels and obtain satisfactory results. However, the fourth model, 514G1-N $\varnothing$ nos 8824 and 8825 , taken with Eagle camera no. 15 on July 24 showed residuals on one fiducial mark close to $1 \mathrm{~mm}$, which is a very high value, and the relative orientation also gave very poor results. The optical quality of these photographs is similar to other photographs taken with the Eagle camera 15 and is found to be of good geometrical quality, so the errors do not show up visually.

Errors during photography, or during storage, are likely sources of the large residuals. Thus, geologists should be aware during the planning stage that not all old photographs are of sufficient geometrical quality.

Control points needed for the absolute orientation of the stereopairs were digitized from topographic maps on the scale 1:250 000, and shore lines, intersecting rivers and mountain tops were identified and used.

The topographic maps of Nûgssuaq and northern Disko are of poor general quality and for this reason the identification of points is difficult. Therefore, the accuracy of the absolute orientation was low i.e. $30 \mathrm{~m}(1 \sigma)$ in plane and $5 \mathrm{~m}(1 \sigma)$ in elevation. Because of the oblique view the points were widely spaced (more than $30 \mathrm{~km}$ apart). Therefore, the standard errors on the scale in the orientated model were better than $1 \%$ in spite of the fairly large co-ordinate deviations. This was found to be satisfactory because the aim of the present experiment was relative measurements within a limited area.

The relative pointing precision varies over the model 


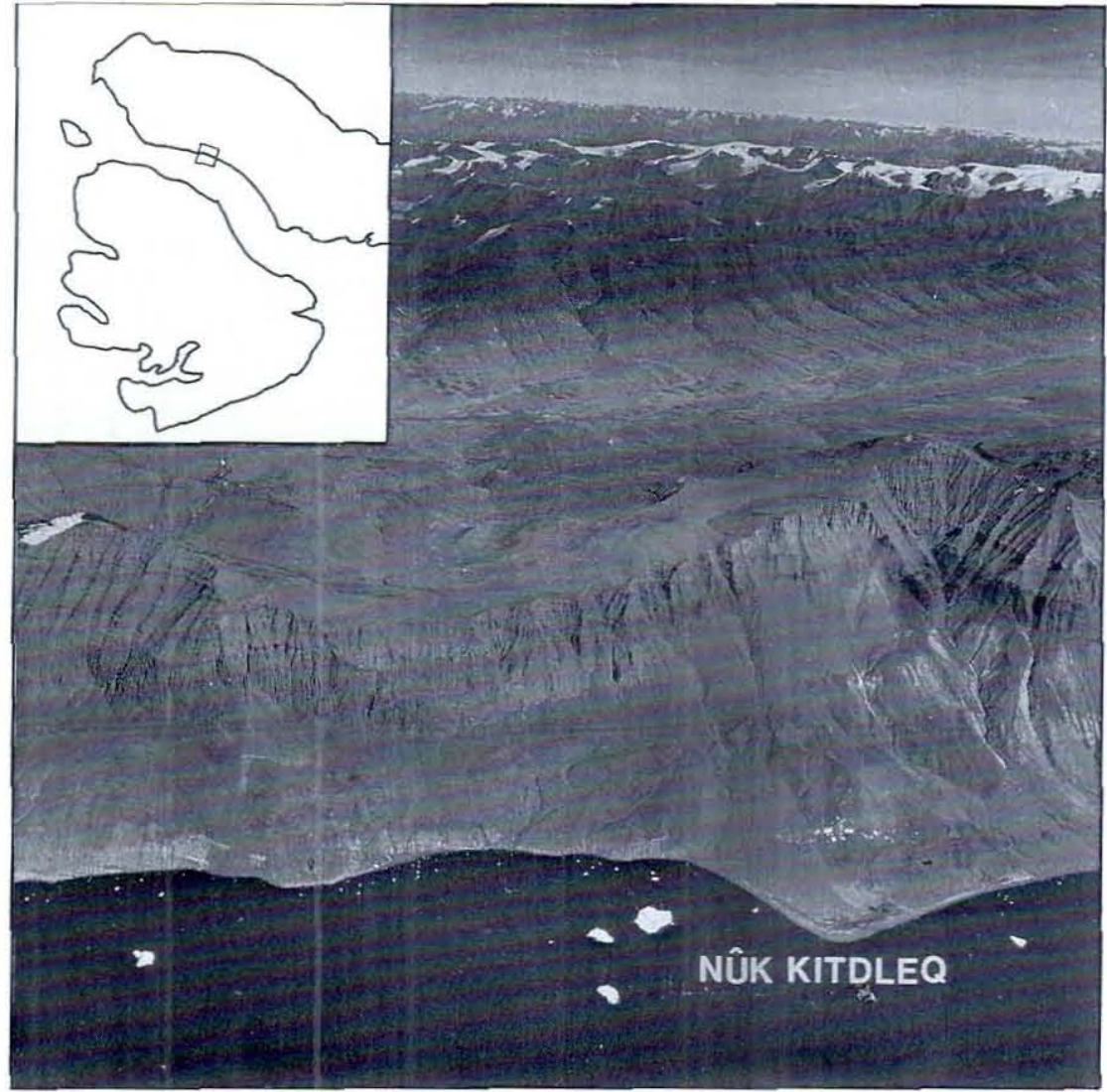

Fig. 1. Part of oblique photograph 514G1-NØ no 8840 from Nûk kitdleq at the south coast of Nûgssuaq. Courtesy Geodætisk Institut, Denmark.

because the oblique view gives a varying photographic scale. The mountain sides of interest were normally situated at a distance of about $7-8 \mathrm{~km}$ from the camera, resulting in a photographic scale of about 1:50 000 .

As judged from the relative orientation, the photogrammetric precision obtained was about 20 microns, which gives a relative pointing error of about 1 metre at the scale 1:50 000. The resolution of the old photographs only allowed for a magnification of about five times, so that the photogrammetric interpreter observed the mountain side of interest at a scale of about 1:10 000 .

During the project photograph overlaps of about 60 and $80 \%$ were tested. Although the mountain side of interest was close to orthogonal to the photograph direction, it was difficult to maintain the stereoscopic view at $60 \%$ overlap during the operation. Therefore, $80 \%$ overlap was used and is recommended for future work although the accuracy of measurement is about half that for $60 \%$ overlap.

\section{Work procedure}

The models were orientated by a photogrammetric operator, who took about two to three hours due to the troublesome work of finding and digitizing points from the topographic maps. Subsequently, contours were digitized by the photogrammetric operator, whereafter the geologist interpreted and digitized the relevant geological features in the model. Simultaneously with the data collection, a test plot was produced on an on-line plotting table. The average time spent by the geologist on a $10 \mathrm{~km}$ long profile was two days.

After the data collection, different views were plotted from the data-files. For this project a normal orthogonal projection, a section, and a perspective plot were drawn, and examples are given in figs 2 and 3 .

\section{Geological interpretation}

The selected model, from Nûk kitdleq on the south coast of Nûgssuaq, was interpreted and measured photogrammetrically. Observations on the stereo model were supplemented by visual inspection of a series of colour slides taken in the model area from a helicopter. The features studied were the pre-Quaternary sedimentary and volcanic lithologies, with the main emphasis on the volcanic rocks from the Vaigat Formation. The 
three main lithologies are Cretaceous clastic sediments, Tertiary hyaloclastites and lava flows.

The exposures with Cretaceous sediments can be mapped easily, and several metre-thick units of sandstone or shale can be measured when they are not obscured by scree and landslides. Solifluction makes strike and dip measurements uncertain but it is easy to ascertain that sediments in the western part of the model show apparent dips of 6 to $9^{\circ}$ towards the east, while sediments in the eastern part of the model are sub-horizontal.

The hyaloclastite basins are very suitable for this type of photogrammetry. Thickness of hyaloclastite units, and strike and dip of foresets can easily be measured and units with different colours can be mapped. The transition from subaerial lava facies to subaqueous hyaloclastite facies is easily recorded. As an example, lava flow $a$ (fig. 2) developed into hyaloclastite foreset $a$ with a strike of $01^{\circ}$ and a dip of $27^{\circ} \mathrm{E}$, and the water depth of. the basin at the time of eruption of lava $a$ was more than $491 \mathrm{~m}$.

The varying erosion resistance and colours of the subaerial lava flows make it possible to map a sequence of lava flows and some individual lavas. Structures and variations in thickness of flows or series of flows as well as dips and strikes are easily measured. The method is not well suited for measuring and mapping dykes and faults cutting at oblique angles to the direction of observation.

The area of the model was subsequently visited in the field (Larsen \& Pedersen, 1988) and the photo-interpreted features were found to be correctly recorded. However, some geologically important features which are not clearly distinguishable on the old photographs were also found.

\section{Conclusion}

During the project we found that the oblique view has the following advantages:

(1) The steep mountain sides facing the camera provide an excellent target for photo-interpretation.

(2) The angle of sight is suitable for some map projections and excellent for the construction of vertical sections.

(3) The angle of sight, which resembles that of the geologist's normal field situation, is of great help in the interpretation of the geology of sub-horizontal and dipping lithological sequences.

(4) In some models the oblique view permitted the identification of marker horizons over distances of up to $100 \mathrm{~km}$, which may be very useful in reconnaissance work.
The following general problems were encountered with the use of oblique as opposed to vertical photographs:

(1) It is very difficult to base regional mapping on oblique photographs alone because of the varying scale and the shadowed areas.

(2) It takes more practice for the geologists to use the measuring mark in the oblique view than in vertical views.

The following special problems were encountered for the actual photographs taken with Eagle cameras around 1949:

(1) Photographs from one flight line were of poor geometrical quality.

(2) Photographs are of greatly varying quality for resolution and sharpness of details. Generally a magnification of more than five times brings out the grain in the photograph. Modern photographs would allow a much higher magnification.

However, despite these shortcomings, valuable geological information can be extracted from all the investigated photographs, though with variable geometrical accuracy and information density. In general, the methods are very suitable for producing detailed sections and profiles. Due to shadowed areas, however, regional mapping projects should still be based on vertical aerial photographs.

The variable quality of the old oblique photographs and the wide spacing on the flight lines raise the question of how to obtain new oblique photographs for geological investigations where, owing to financial and practical factors, new photographic missions with modern photogrammetric cameras cannot be expected. For this reason we have started experimental work on oblique photogrammetry with a series of colour diapositives taken with a Hasselblad camera from a helicopter. Several photographic series taken by F. Ulff-Møller for us in the Disko and Nûgssuaq areas in the summer of 1987 gave encouraging results.

Acknowledgements. The project is being carried out as a cooperative programme between the Institute of Surveying and Photogrammetry (ILF) at the Technical University of Denmark, the Geological Survey of Greenland, and the Geological Museum of Copenhagen. The project is supported by the Danish Natural Science Research Council and the Danish Technical Science Research Council.

\section{References}

Dueholm, K. S. \& Garde, A. A. 1986: Geological photogrammetry using standard colour slides. Rapp. Grønlands geol. Unders. 130, 69-74. 


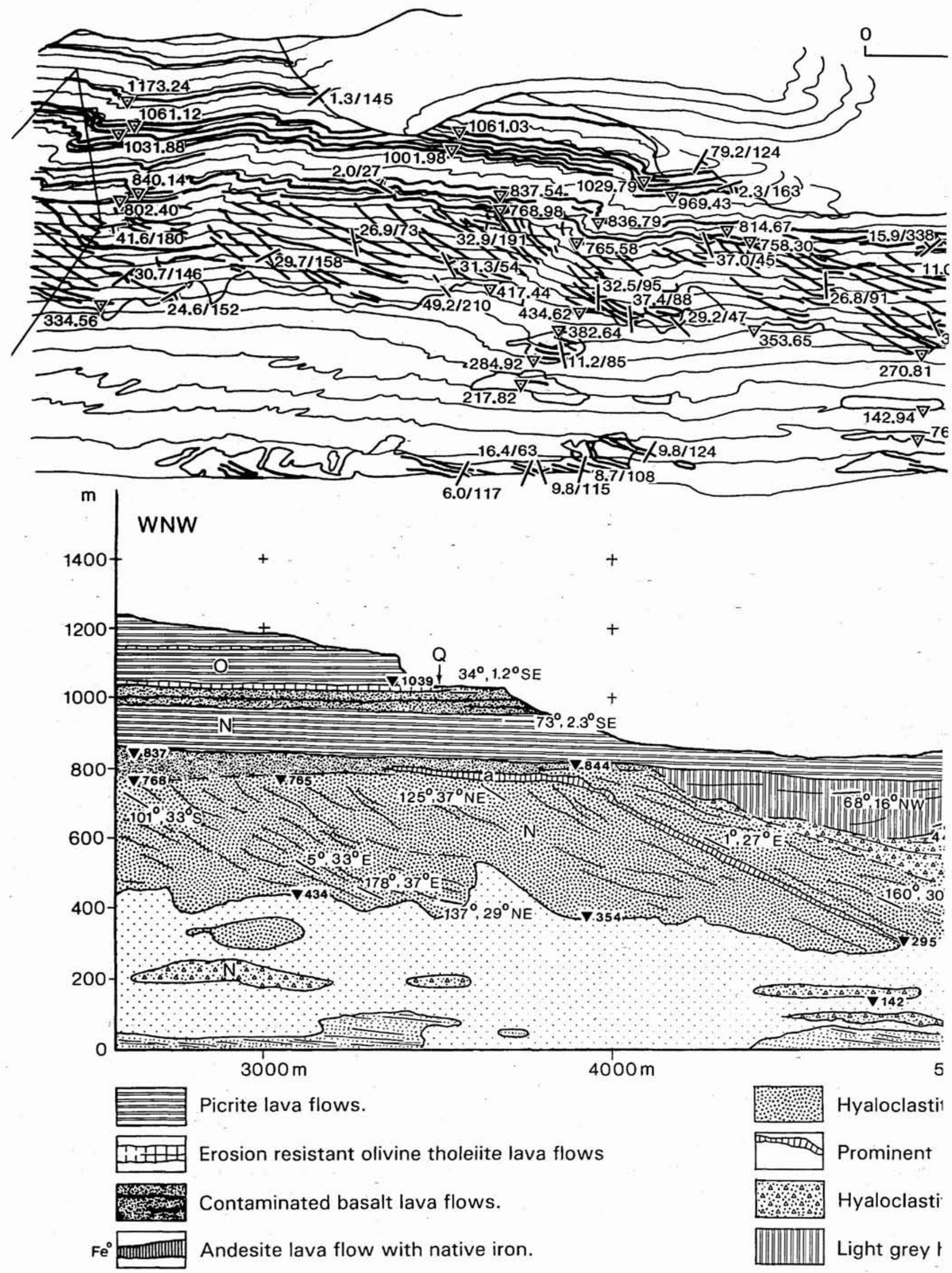




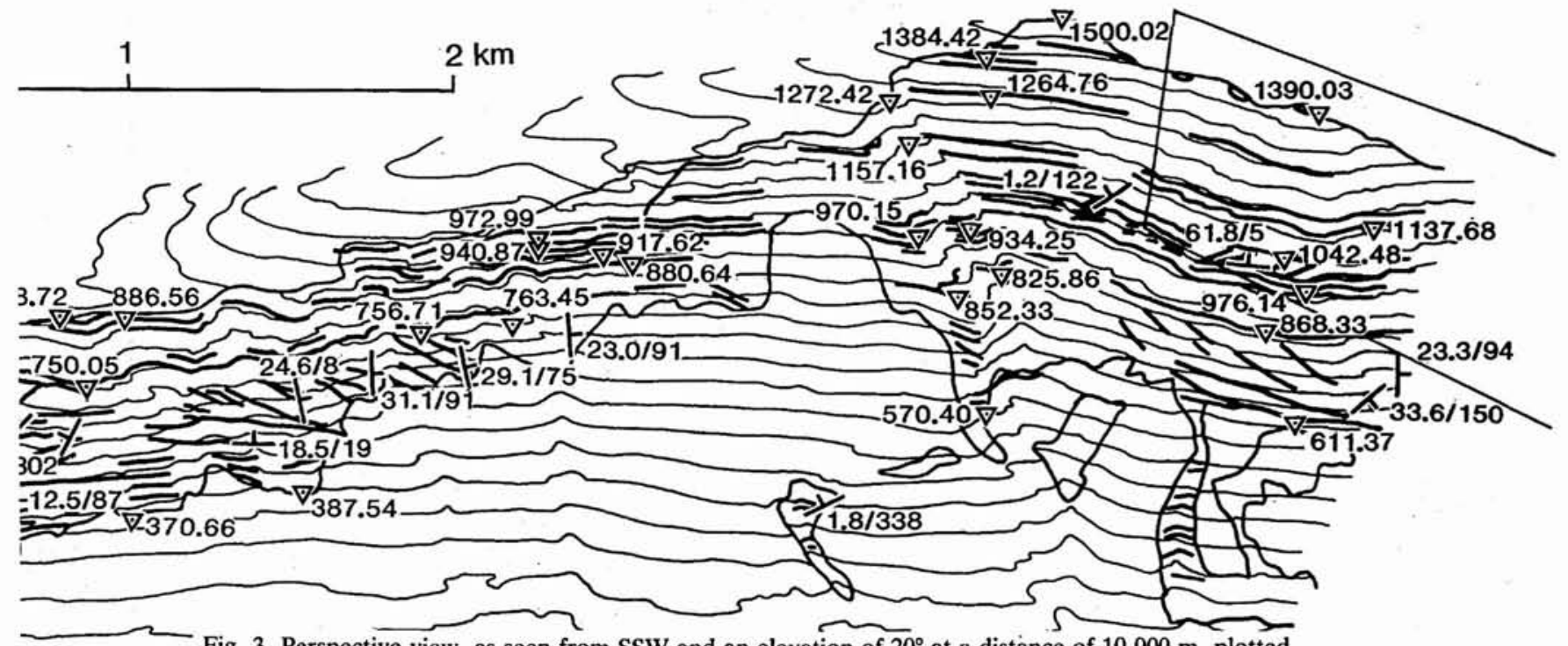

Fig. 3. Perspective view, as seen from SSW and an elevation of $20^{\circ}$ at a distance of $10000 \mathrm{~m}$, plotted from data digitized from the photogrammetric model 514G1-N $\varnothing$ nos 8839 and 8840.

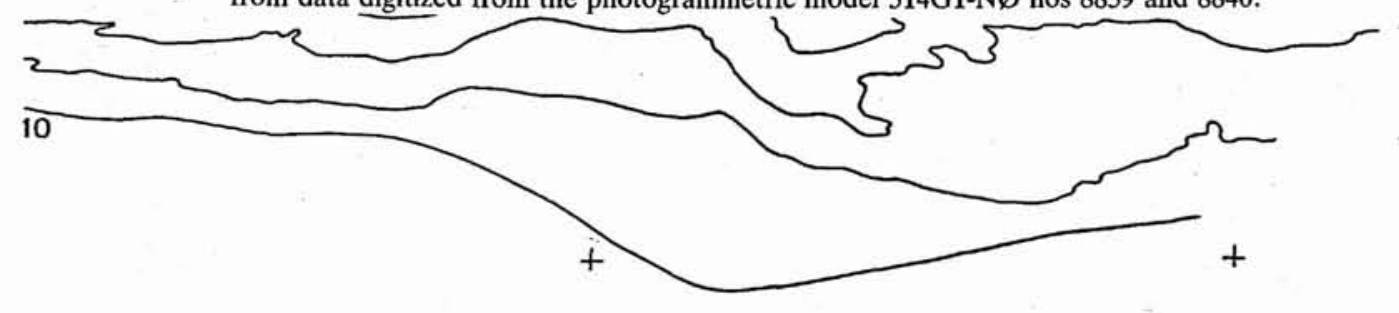


Heinesen, M. 1987: Nedre tertiære basaltbreccier og undervands-lavastrømme, sydlige Disko, Vestgrønland: Strukturelle, petrografiske og mineralogiske studier. Unpublished cand. scient. thesis. Københavns Universitet.

Koch, B. E. 1959: Contribution to the stratigraphy of the non-marine Tertiary deposits on the south coast of the Nûgssuaq Peninsula, northwest Greenland. Bull. Grønlands geol. Unders. 22 (also Meddr Grønland 162,1) 100 pp.

Larsen, L. M. \& Pedersen, A. K. 1988: Investigations of
Tertiary volcanic rocks along the south coast of Nûgssuaq and in eastern Disko, 1987. Rapp. Grønlands geol. Unders. 140 (this report).

Pedersen, A. K. 1985: Lithostratigraphy of the Tertiary Vaigat Formation on Disko, central West Greenland. Rapp. Grønlands geol. Unders. 124, $30 \mathrm{pp}$.

Pedersen, A. K. \& Larsen, L. M. 1987: Early Tertiary volcanic rocks from eastern Disko and south-eastern Nûgssuaq. Rapp. Grønlands. geol. Unders. 135, 11-17.
K. S. D.,

Institut for Landmàling og Fotogrammetri,

Danmarks Tekniske Højskole,

Landmälervej 7 ,

DK-2800 Lyngby,

Denmark.
A. K. P.,

Geologisk Museum, $\emptyset$ ster Voldgade 5-7, $D K-1350$ Copenhagen $K$, Denmark.

\title{
Examples of bar accretion in fluvial sand, the Atane Formation, eastern Disko, West Greenland
}

\author{
Gunver Krarup Pedersen and Morten Willaing Jeppesen
}

The aim of the present paper is to supply additional sedimentological observations and to add new details to the existing interpretation of the Atane Formation on eastern Disko. Examples of epsilon cross-bedding reflect formation of point bars and indicate intermittent development of sinuous channels in the coarse-grained braided river. Large tabular sets of planar cross-bedding are interpreted as transverse bars and the coalescence of two such bars are discussed in detail. The field work was carried out during five days in July 1987 as part of a sedimentological research project supported by GGU and financed by SNF.

\section{Background}

White to pale yellow, slightly consolidated sand is widely exposed on eastern Disko below the Tertiary volcanic rocks. The sand was deposited in $10-40 \mathrm{~m}$ thick sequences capped by relatively thin clay horizons and eventually by coal seams. Palaeobotanical studies of these indicate a late Cretaceous age (Miner, 1932) and the sand is referred to the Atane Formation (Henderson et al., 1976).

Johannessen \& Nielsen (1982) and Bennike et al. (1981) studied the Atane Formation at Pingo and Skansen (fig. 1) and suggested deposition by a sandy braided river. They based their interpretation on the predominance of current-generated sedimentary structures, the unimodal palaeocurrents and the lack of channel abandonment or classical, fining-upwards point bar sequences characteristic of meandering rivers. The

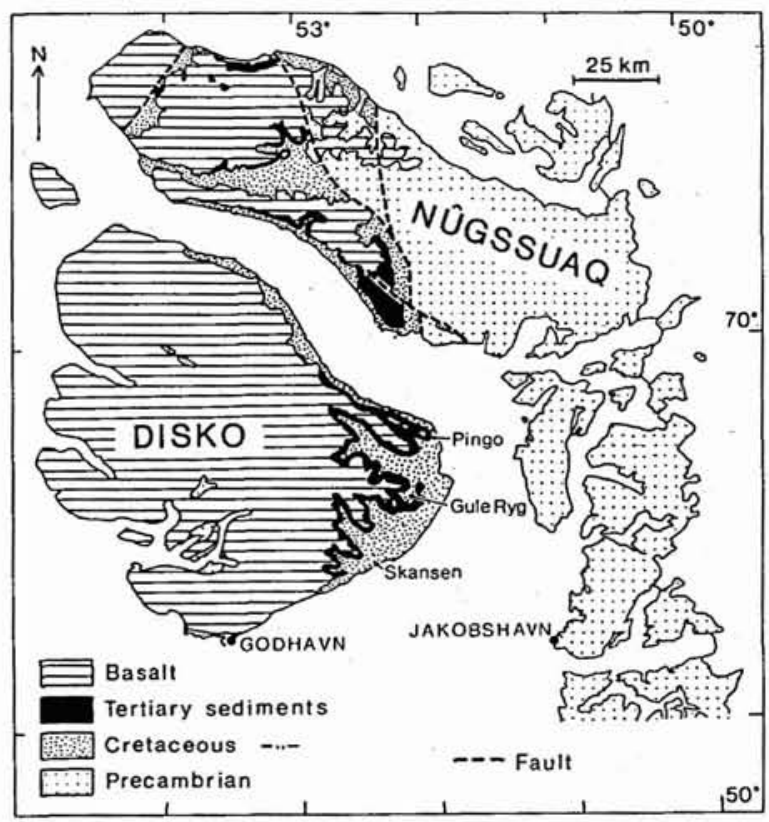

Fig. 1. Location map, showing the distribution of the Cretaceous sediments in the Nûgssuaq Embayment and the localities where the fluvial sediments have been studied. 